\title{
Protein signature linking history of miscarriages and metabolic syndrome: A proteomic study among North Indian women
}

\author{
Saurabh Sharma ${ }^{1}$, Suniti Yadav ${ }^{2}$, Ketaki Chandiok ${ }^{2}$, Radhey Shyam Sharma ${ }^{1}$, Vandana Mishra ${ }^{\text {Corresp.., }}{ }^{1}$, \\ Saraswathy Nava Kallur Corresp. 2 \\ 1 Bioresources \& Environmental Biotechnology Laboratory, Department of Environmental Studies, University of Delhi, New Delhi, New Delhi, India \\ 2 Molecular Anthropology Laboratory, Department of Anthropology, University of Delhi, New Delhi, New Delhi, India \\ Corresponding Authors: Vandana Mishra, Saraswathy Nava Kallur \\ Email address: mistletoe_h@hotmail.com, knsaraswathy@yahoo.com
}

Background. Metabolic syndrome (MeS), a constellation of metabolic adversities, and history of miscarriage make the women at a higher risk for cardiovascular diseases (CVDs). However, molecular evidence indicating a link between the two phenotypes (history of miscarriage and MeS) among women would offer an opportunity to predict the risk factor for CVDs at an early stage. Thus, the present retrospective study attempts to identify the proteins signatures (if any) to understand the connection between the history of miscarriage and MeS. Methods. Age-matched eighty pre-menopausal women who were not on any medical intervention or drugs were recruited from a Mendelian population of the same gene pool. Recruited women were classified into four groups - (a) Group A absolute cases with history of miscarriage and MeS, (b) Group B - absolute controls without any history of miscarriage and MeS, (c) Group C - cases with MeS but lack any history of miscarriage, (d) Group D - cases with history of miscarriage but lack MeS. Differentially expressed proteins in plasma samples of women from four groups were identified using 2-D gel electrophoresis and mass spectrometry. Results. Three case groups $(A, C, \& D)$ showed eighteen differentially expressed proteins. Nearly $60 \%$ of proteins (11/18) were commonly dysregulated in Group C (only with MeS) and Group D (only with miscarriage history). Nearly $40 \%$ of proteins (7/18) were commonly dysregulated in the three case groups (Groups $A, C, \& D$ ), indicating a shared pathophysiology. Four proteins were exclusive but shared by case groups $C \& D$ indicating the independent routes for CVDs through MeS or miscarriages. In absolute cases, transthyretin (TTR) showed exclusive upregulation, which was further validated by Western blotting and ELISA. Networking analyses showed the strong association of TTR with haptoglobin, transferrin and ApoAl hinting towards a cross-talk among these proteins which could be a cause or an effect of TTR upregulation. Conclusion. The study provides 
evidence for molecular links between the history of miscarriage and MeS through a putative role of TTR. However, longitudinal follow-up studies with larger sample size would further help to demonstrate the significance of $T R$ and other targeted proteins in risk stratification and the onset of CVDs. 
1

2

4

5 Saurabh Sharma ${ }^{1, \uparrow}$, Suniti Yadav, Ketaki Chandiok ${ }^{2}$, Radhey Shyam Sharma ${ }^{1}$, Vandana

6 Mishra $^{1, *}$, Kallur Nava Saraswathy ${ }^{2, *}$

7

$8{ }^{1}$ Department of Environmental Studies, Bioresources \& Environmental Biotechnology

9 Laboratory,

10 University of Delhi, Delhi, INDIA

$11{ }^{2}$ Department of Anthropology, Molecular Anthropology Laboratory, University of Delhi, Delhi,

12 INDIA

13 * Corresponding authors

14 These authors contributed equally to this work

15 Corresponding Authors E-mail: knsaraswathy@yahoo.com (KNS)

16

17 Email address of co-authors: saurabh1987sharma@gmail.com (SS); suniti_2004@yahoo.com (SY);

chandiokketaki@gmail.com (KC),rads26@hotmail.com (RSS) 


\section{Abstract}

Background. Metabolic syndrome (MeS), a constellation of metabolic adversities, and history of miscarriage make the women at a higher risk for cardiovascular diseases (CVDs). However, molecular evidence indicating a link between the two phenotypes (history of miscarriage and $\mathrm{MeS}$ ) among women would offer an opportunity to predict the risk factor for CVDs at an early stage. Thus, the present retrospective study attempts to identify the proteins signatures (if any) to understand the connection between the history of miscarriage and MeS.

Methods. Age-matched eighty pre-menopausal women who were not on any medical intervention or drugs were recruited from a Mendelian population of the same gene pool. Recruited women were classified into four groups - (a) Group A - absolute cases with history of miscarriage and MeS, (b) Group B - absolute controls without any history of miscarriage and MeS, (c) Group C - cases with MeS but lack any history of miscarriage, (d) Group D - cases with history of miscarriage but lack MeS. Differentially expressed proteins in plasma samples of women from four groups were identified using 2-D gel electrophoresis and mass spectrometry.

Results. Three case groups (A, C, \& D) showed eighteen differentially expressed proteins. Nearly $60 \%$ of proteins (11/18) were commonly dysregulated in Group C (only with MeS) and Group D (only with miscarriage history). Nearly $40 \%$ of proteins (7/18) were commonly dysregulated in the three case groups (Groups A, C, \& D), indicating a shared pathophysiology. Four proteins were exclusive but shared by case groups C \& D indicating the independent routes for CVDs through MeS or miscarriages. In absolute cases, transthyretin (TTR) showed exclusive upregulation, which was further validated by Western blotting and ELISA. Networking analyses showed the strong association of TTR with haptoglobin, transferrin and ApoA1 hinting towards a cross-talk among these proteins which could be a cause or an effect of TTR upregulation. 
44 Conclusion. The study provides evidence for molecular links between the history of miscarriage and MeS through a putative role of TTR. However, longitudinal follow-up studies with larger sample size would further help to demonstrate the significance of TTR and other targeted proteins in risk stratification and the onset of CVDs.

\section{INTRODUCTION}

Metabolic syndrome (MeS) show a constellation of metabolic adversities, such as central obesity, high glucose, high blood pressure, high triglycerides and low high-density lipoprotein cholesterol (Grundy, 2005). Individuals with MeS become susceptible to develop cardiovascular diseases (CVDs) and diabetes and such individuals show high mortality compared with those without MeS (Xu et al., 2013). The global trends also confirm that with the increase in MeS the adults also show a parallel increase in risk for CVDs, type-2 diabetes, and hypertension (Ranasinghe et al., 2017). MeS is more prevalent among women as compared with men (Gu et al., 2005; Xi et al., 2009; Lim et al., 2011; Yeh et al., 2011). Likewise, mortality due to CVD's is reportedly higher among women in contrast to men, with distinct characteristics linked to reproductive history among women (Ranthe et al., 2013).

As a general belief, women remain protective against certain CVDs (such as atherosclerosis) as compared with men (Sharma \& Gulati, 2013), however such difference is attenuated in women with a history of adverse pregnancy events owing to underlying mechanisms that share the etiology of CVDs (Maino et al., 2016). For example, preeclampsia, stillbirth, and preterm birth exert similar effects on endothelium and vascular system despite different etiologies. Atherosclerotic changes and inflammation in the vascular bed link adverse pregnancy and cardiovascular events (Sharma \& Gulati, 2013), therefore, women with history of pregnancy complications may develop high risk for different CVDs in later life (coronary heart 
67 disease, ischemic heart disease, myocardial infarction, etc.) (Germain et al., 2007; McDonald et 68 al., 2008; Oliver-Williams et al., 2013; Parker et al., 2014). Some studies also suggested that 69 woman after each additional miscarriage becomes more susceptible to myocardial infarction, 70 cerebral infarction and renovascular hypertension as compared with women without a history of 71 miscarriage (Sharma \& Gulati, 2013). Pregnancy loss-induced inflammatory alterations 72 (metabolic, hormonal and hemostatic) may contribute to the development of CVDs suggesting a 73 shared pathological mechanism (Kharazmi et al., 2011; Fraser et al., 2012; Xu et al., 2013), 74 however the molecular link between both the conditions is not yet well established.

Human diseases are often treated separately, but they are mostly associated because of physiological interactions among common proteins, metabolic relationships, or interaction between signalling pathways. Analysis of common proteins among exclusive cases of two independent diseases and its comparison with the cases with co-occurrence of both the diseases has been central to decipher the finer molecular links between the two metabolic states. Thus, it is important to investigate the molecular signatures that can link history of miscarriage and MeS for risk stratification in women for CVDs. Women with a history of miscarriage(s) but at a preCVD condition, i.e. MeS form an ideal population for early therapeutic intervention for reducing the risk to the onset of CVDs (Grundy, 2005). However, epidemiological studies associating miscarriages to the elevated risk of MeS have not yet been conducted. A cohort study to identify dysregulated proteins in plasma of women with either of the conditions (MeS or miscarriage) or both miscarriage and MeS as compared with the absolute controls is a prerequisite to discover

87 highly predictive biomarkers of CVDs for improving disease stratification methods and 88 developing intervention or prevention methods for CVDs. 

the plasma protein expression patterns among women with a history of miscarriage and MeS to

91 identify the biomolecular links between the two health conditions. The protein signature linking 92 the two health conditions (history of pregnancy complications and MeS) offers an opportunity to 93 predict the risk for CVDs among women at an early stage.

94

\section{MATERIALS AND METHODS}

\section{Ethics statement}

The study was approved by Ethics Committee, Department of Anthropology, University of Delhi, New Delhi, India (Ref. No. Anth/2010/455/1). All participants provided pre-informed written consent to participate in this study.

\section{Participants and plasma sample preparation}

Fieldwork was carried out in fifteen different villages of Palwal District of Haryana State, India $\left(28.1487^{\circ} \mathrm{N}, 77.3320^{\circ} \mathrm{E}\right)$. One thousand fourteen married women of 30-65 years were selected from a Mendelian population of same gene pool to participate in the study. Each of the recruited women was subject to structured interview schedule for collection of data on household composition and reproductive history after obtaining pre-informed written consent from each participant. Since menopause itself is a risk factor for adverse cardiovascular outcomes, women with menopause (both natural and surgical) $(\mathrm{N}=447)$ were excluded for the study. Five women in perimenopausal phase were also excluded. Of the 1009 recruited females, 562 women were in the premenopausal category with an age of 30-46 years. These women were categorized into four groups: (i) Group A - absolute cases with history of miscarriage and MeS, (ii) Group B - 
112 absolute controls without any history of miscarriage and MeS, (iii) Group C - cases with MeS

113 but lack any history of miscarriage, and (iv) Group D - cases with history of miscarriage but

114 lack MeS. Age-matched women were selected from each group resulting into a total sample size

115 of $\mathrm{N}=80$ for the present study (20 each group). Any woman who has experienced one or more

116 spontaneous pregnancy loss or abortion till the second trimester of the pregnancy is grouped in

117 the case of history of miscarriage (Group D). Woman was classified with MeS (Group C)

118 following guidelines of NCEP-ATP (III) 2005 Revised Guidelines (Huang 2009), i.e. a case of

119 MeS shows the presence of a minimum of three abnormalities out of waist circumference, fasting 120 glucose, triglyceride levels, HDL levels and blood pressure. Exclusion criteria included 121 menopause, established cardiovascular diseases (like myocardial infarction, angina, etc.), and 122 medication for any disease/infection in the past one month (Supplementary Table1).

123 The blood samples from twenty women (subjects) from Group A (absolute cases) were

124 collected. Similarly, age-matched subjects were selected from the other three groups (groups B, $125 \mathrm{C} \& \mathrm{D})$ and 60 blood samples were collected. Eighty blood samples for analyzed for the present 126 study. Intravenous blood sample $(5 \mathrm{ml})$ was collected in evacuated tubes with and without EDTA 127 (2.5 mL each) from every participant after overnight fasting, and the sample was transported on 128 ice to the Molecular Anthropology Laboratory, Department of Anthropology, University of 129 Delhi within $2 \mathrm{~h}$ of collection and processed for further analysis. Plasma was separated from 130 evacuated tubes with EDTA after centrifugation at $3000 \times g$ for $10 \mathrm{~min}$. Serum was separated 131 from evacuated tubes without EDTA after centrifugation at $3000 \times g$ for $10 \mathrm{~min}$. Plasma and 132 serum samples were aliquoted for single use (to avoid repeated freezing-thawing of the sample) 133 and stored at $-80^{\circ} \mathrm{C}$ till further use. Serum sample was characterized for biochemical parameters 134 (fasting glucose, total cholesterol or TC, triglycerides or TG, high-density lipoprotein-cholesterol 
135 or HDL-C) using enzymatic assay by spectrophotometry within $24 \mathrm{~h}$ of sample collection. The

136 protein content of plasma samples was determined by Bradford's dye-binding method using BSA

137 (bovine serum albumin) as standard (Bradford, 1976).

138

139

\section{2-Dimensional gel electrophoresis and analysis of gel images}

140 To analyze differential protein expression in different case groups and to discern the proteomic 141 link between the history of miscarriage and MeS, plasma proteins of different case groups were 142 subjected to 2-dimensional gel electrophoresis. The protein profiles of case groups A, C \& D 143 were compared with group B. Each protein sample $(50 \mu \mathrm{g})$ was mixed with rehydration buffer (7

$144 \mathrm{M}$ urea, $2 \mathrm{M}$ thiourea, 2\% CHAPS containing $40 \mathrm{mM}$ dithiothreitol or DTT and $0.2 \%$ ampholyte, 145 Sigma-Aldrich, USA). Isoelectric focusing (IEF) was carried out using Protean IEF cell (Bio146 Rad, USA) as pre manufacturer's protocol. Proteins were separated in the first dimension using 147 IPG strips (immobilized $\mathrm{pH}$ gradient strips, $\mathrm{pH}$ 4-7, $7 \mathrm{~cm}$, Bio-Rad, USA). The IEF conditions 148 used were: $200 \mathrm{~V}$ for $1 \mathrm{~h}$ followed by $500 \mathrm{~V}$ for $1 \mathrm{~h}$ and $1000 \mathrm{~V}$ for next $1 \mathrm{~h}$ and rest of the 149 focusing at $8000 \mathrm{~V}$ for $5 \mathrm{~h}$ for a total of $13000 \mathrm{VH}$ (Bio-Rad, USA). After completing the IEF, 150 strips were equilibrated for $20 \mathrm{~min}$ each in equilibration buffer [(50 mM Tris-HCl, $\mathrm{pH} 8.8,6 \mathrm{M}$ urea, 4\% (w/v) SDS, and 20\% (w/v) glycerol) with $10 \mathrm{mg} / \mathrm{ml}$ DTT followed by that containing

$15240 \mathrm{mg} / \mathrm{ml}$ iodoacetamide (Sigma-Aldrich, USA). Proteins were further separated in the second 153 dimension using SDS-PAGE (12\%-5\% gel system). The gels were silver stained and analyzed 154 using Alpha Digidoc 1201 software. The densities of protein bands of groups A, C, \& D were 155 compared with group B. Any protein band from groups A, C \& D showing a $\geq 1.2$ fold change in 156 density than that of group B was considered differentially expressed. The relative intensities of 
157 protein spots were determined, and densitometric results were subjected to cluster analyses

158 (Saroha et al., 2012).

159

160 In-gel digestion of proteins

161 To extract the protein from silver-stained gels, the gel blocks containing protein spots were 162 carefully excised and trypsinized using trypsin gold following manufacturer's protocol 163 (Promega, USA). The gel blocks were washed with deionized water and kept in destaining 164 solution $\left(0.2 \% \mathrm{~K}_{3} \mathrm{FeCN}_{6}\right.$ and $0.04 \% \mathrm{Na}_{2} \mathrm{~S}_{2} \mathrm{O}_{3}$, Sigma-Aldrich, USA) till the stain disappeared. 165 The washing was continued with $100 \mathrm{mM} \mathrm{NH}_{4} \mathrm{HCO}_{3}$ and $100 \% \mathrm{CH}_{3} \mathrm{CN}$ in 1:1 ratio. The gel 166 blocks were dehydrated with $40 \mu \mathrm{l}$ of 1:1 acetonitrile (ACN) and deionized water for 15 min and 167 then washed with $40 \mu \mathrm{l}$ of $\mathrm{ACN}$. The gel blocks were treated with $50 \mu 1$ of $100 \mathrm{mM}$ ammonium 168 bicarbonate followed by $50 \mu \mathrm{ACN}$ (Sigma-Aldrich, USA). The gel blocks were digested with $16910 \mu \mathrm{l}$ digestion buffer containing $0.1 \mu \mathrm{g}$ trypsin/ $\mu 1$ (Promega, USA) for $45 \mathrm{~min}$ on ice. The $60 \mu \mathrm{l}$ 170 digestion buffer without trypsin $\left(1 \mathrm{M} \mathrm{CaCl}_{2}, 1 \mathrm{M} \mathrm{NH}_{4} \mathrm{CO}_{3}\right)$ was added again and incubated at $17137^{\circ} \mathrm{C}$ for overnight. Supernatants were collected and dried in a vacuum centrifuge. The peptides 172 were extracted by varying the concentration of ACN and trifluoroacetic acid (TFA). Gel pieces 173 were sonicated in a water bath for $30 \mathrm{~min}$, dried in speed-vac to remove remaining TFA and ACN 174 and finally stored at $-20^{\circ} \mathrm{C}$ till further use (Wang et al., 2012)

\section{Matrix-assisted laser desorption ionization-MS/MS}

177 To identify the differentially expressed proteins, the trypsinized peptides were analyzed by 178 MALDI-TOF MS/MS (Applied Biosystems, Life Technologies, USA) system. One microlitre of 179 peptide solution was mixed with an equal amount of $\alpha$-cyano hydroxy cinnamic acid (CHCA) 
180

181

182

183

184

185

186

187

188

189

190

191

192

193

194

195

196

197

198

199

200

201

202

matrix solution prepared in $70 \% \mathrm{CH}_{3} \mathrm{CN}$ and $30 \%$ of $0.1 \% \mathrm{TFA}$. Minimum $\mathrm{S} / \mathrm{N}$ (signal/ noise)

filter was set at $25 \mu \mathrm{m}$ with an exclusion list for $\alpha$-cyano-4-hydroxycinnamic acid (CHCA) matrix peaks for the MS/MS precursor selection. A statistically significant probability of the proteins acceptance was based on Mowse score $(\mathrm{p} \leq 0.05)$.

\section{Western blotting}

The altered expression of TTR in the plasma of all the three case groups, i.e. Group A, C, and D was evaluated using Western blot analysis. Plasma samples of all four groups were separated on 12\%-5\% SDS-PAGE and transferred onto nitrocellulose membrane (Millipore, USA). To reduce the chance of non-specific binding, the membrane was blocked using 5\% BSA (SigmaAldrich, USA) in $1 \times$ PBS (phosphate buffered saline, Merck Chemicals, Germany) for $1 \mathrm{~h}$ at RT with shaking. Anti-TTR (Abcam, USA) (1:3000) and GAPDH (1:1000) were used as a primary antibody for $2 \mathrm{~h}$ at RT. The membrane was then incubated with horseradish peroxidase (HRP) conjugated anti-mouse antibody for $1 \mathrm{~h}$ with mild shaking. After each step, the membrane was washed with PBST to remove unbound proteins and antibody. Enhanced chemiluminescence assay (ECL) was used to develop the membrane as per manufacturer's protocol (G-Biosciences, USA) (Mishra et al., 2018). Variation in expression of TTR was analyzed by comparing intensities of the signals observed in the absolute case group (Group A) with that of the absolute control (Group B), only MeS (Group C) and only history of miscarriage (Group D).

\section{ELISA}

To evaluate the expression pattern of TTR, ELISA was carried out using plasma samples in all the groups $\mathrm{A}, \mathrm{B}, \mathrm{C}$ and $\mathrm{D}(\mathrm{N}=20$ each). Each well of a 96-well microtiter plate (Thermo Scientific, Nunc, USA) was coated with anti-TTR antibody (ProSci Antibody, USA) in 1:2000 
203 dilution with coating buffer $\left(0.01 \mathrm{M} \mathrm{Na}_{2} \mathrm{CO}_{3}\right.$ and $\left.0.035 \mathrm{M} \mathrm{NaHCO}_{3}, \mathrm{pH} 9.6\right)$ and incubated at

$2044^{\circ} \mathrm{C}$ for overnight. Next day, the plate was washed three times with $100 \mu \mathrm{PBST}$ (phosphate

205 buffered saline with tween 20) and incubated with $200 \mu$ l blocking buffer (2\% BSA, Sigma-

206 Aldrich, USA) for $1 \mathrm{~h}$ at RT. The blocking buffer was removed, washed and incubated with

207 primary antibodies for $3 \mathrm{~h}$ at RT. After treating with primary antibody, plates were washed and

208 incubated with $100 \mu \mathrm{l}$ of anti-mouse HRP conjugate secondary antibody for $1 \mathrm{~h}$. The membrane

209 was developed with ortho phenylene diamine $(1 \mathrm{mg} / \mathrm{ml}$ in $0.05 \mathrm{M}$ citrate buffer and $5 \mu 1 / \mathrm{ml}$

$210 \mathrm{H}_{2} \mathrm{O}_{2}$, Sigma-Aldrich, USA) for $30 \mathrm{~min}$. The reaction was stopped by adding $2 \mathrm{~N} \mathrm{H}_{2} \mathrm{SO}_{4}$ to each

211 well and $\mathrm{OD}_{492 \mathrm{~nm}}$ was measured using ELISA plate reader (Biswas et al., 2013).

212

213 Protein networking analysis

214 Differentially expressed proteins were functionally annotated, and their network of interactions

215 was predicted using bioinformatics web tools. Blast2Go bioinformatics platform (Conesa \&

216 Götz, 2008) was used for functional annotation of eighteen proteins differentially expressed in

217 different case groups. To understand the possible biological processes linking the history of

218 miscarriage with $\mathrm{MeS}$, protein-protein interactions were examined: (i) involving all the 18

219 differentially expressed proteins, and (ii) considering only the 7 proteins (HP proteins, ApoA1,

220 transferrin, Serpin38 and SYNE 1) commonly dysregulated in all the three case groups and TTR

221 (involved only in absolute cases exclusively). Functional association among differentially

222 expressed proteins in all case groups was revealed by networking analysis using STRING

223 webtool (Search Tool for the Retrieval of Interacting Genes/Proteins ver 10.0). The analyses

224 were based on the known and predicted protein-protein interactions (physical and functional)

225 available in the database. The database houses the information derived from sources, such as 
226 interactions known from high-throughput experiments, co-expression analysis, and previously

227 available literature, and interactions predicted from computational analyses of genomic

228 characters and gene/protein functions based on orthologs and interologs. The protein-protein

229 interaction with confidence score $\geq 0.700$ was considered. The confidence score is calculated by

230 weighing and integrating the data for all protein interactions. Colored nodes show direct

231 interaction, white nodes show the absence of interaction, whereas the thickness of lines signifies

232 the strength of associations (Bag et al., 2014).

233

234 Statistical Analyses

235 One way ANOVA and principal component analysis was performed using SPSS ver. 16.0 for

236 Windows (SPSS Inc., Illinois, USA) and GraphPad Prism 7.01 for Windows (GraphPad

237 Software, La Jolla, California, USA). Statistical significance was tested at $p<0.05$. Cluster 238 analysis was done using Multiple Experiment Viewer software (MeV, USA).

\section{RESULTS}

\section{Identification of differentially expressed proteins in only miscarriage, only metabolic} syndrome, and absolute cases

243 Densitometric analyses of 2-D gel electrophoretic profiles of plasma proteins of different case 244 groups revealed eighteen differentially expressed proteins in groups A, C \& D (Fig. 1). MALDI245 TOF/MS-MS analysis revealed that eighteen differentially expressed proteins (Table 1) play 246 significant roles in lipid metabolism, ion transport and binding processes in the cell. Most of the 247 proteins (15/18) were upregulated in case groups (A, C \& D), whereas a few (3/18) showed 
248 down-regulation i.e., apolipoprotein A, chain B transferrin binding protein and chain A 249 transferrin.

251 Clustering of differentially expressed proteins based on their expression

252 In cluster analysis, the 18 proteins were segregated based on the expression pattern (Fig. 2A) and 253 therefore, formed 5 clusters (Fig. 2B). Different isoforms of ApoA1 showed different expression 254 patterns, and therefore formed different clusters. In cases with only MeS (Group C), one of the 255 isoforms (S15) was upregulated (cluster 2), while the other isoform (S14) was downregulated 256 (cluster 4). Similarly, the expression pattern of two isoforms of chain A, and transferrin (S2 and 257 S3) also formed distinct clusters (cluster 2 and 3). It may be noted that ApoA1 and chain A, and 258 transferrin are the major components of the vital cellular processes, i.e., lipid metabolism and 259 iron transport, respectively. The distinct functions of these isoforms in different case groups need 260 further analyses. Mostly the proteins were involved in biological regulation and cellular 261 processes followed by the proteins involved in metabolic processes (Fig. 3). The Venn diagram shows the distribution of differentially expressed proteins among three case groups (Fig. 4A and Fig. 4B). Of the eighteen differentially expressed proteins, eleven proteins were shared by the groups $\mathrm{C}(\mathrm{MeS})$ and group D (history of miscarriage) that include, apoA1, transferrin (2 isoforms), chain B transferrin binding protein B, HP proteins (3 isoforms), SYNE protein 1, serpin38, CRA_a and coiled-coil domain protein (regions II \& V). Of these, seven proteins were also shared by Group A case (region V). Cases from group C and group D shared only four dysregulated proteins (region II), whereas group A and group C cases shared only two proteins (region VI). Interestingly, group A and group D cases lacked any shared protein (region IV). The cases from group A (region VII) and group D (region I) showed one 
271 group-specific protein, whereas cases of group C (region III) showed three group-specific

272 proteins. Transthyretin (TTR, S1) showed upregulation in group A (absolute cases) exclusively

273 and occupied distinct quadrant I in the PCA plot (Fig. 4C), so TTR was chosen for further

274 verification in all the samples.

275

276

Analyses of interactions among commonly dysregulated proteins in the case groups

277 The differentially expressed proteins showed varying levels of interactions. For example, TTR,

278 TF, ApoA1, and HP showed strong interactions with each other (Fig. 5A), whereas FGF1

279 showed a weak interaction with TF. The interaction among TTR, TF, ApoA1 and HP remained

280 strong whether we analyzed all eighteen differentially expressed proteins, or only the seven

281 proteins (HP proteins, ApoA1, transferrin, Serpin38 and SYNE 1) commonly dysregulated in the

282 three case groups and TTR (involved only in absolute cases exclusively) (Fig. 5).

283

284

\section{Validation of higher expression of transthyretin in absolute cases}

285

ELISA and Western blot analyses confirmed upregulated expression of TTR in the plasma of

absolute cases with both histories of miscarriage and MeS. As compared with absolute control or

group B ( $\mathrm{n}=20)$, TTR showed significant upregulation in absolute cases or group A, (2.5-fold,

$\mathrm{n}=20)$ only MeS cases or group C (2.23-fold, $n=20)$ and only miscarriage cases or group D (4.1-

fold, $\mathrm{n}=20$ ) (Fig. 6C). Similarly, the densitometric analysis of Western blots validated a

significantly higher expression of TTR in absolute cases (1.56-fold), only MeS cases (1.33-fold)

\section{DISCUSSION}


294 History of miscarriage makes a woman susceptible to metabolic syndrome (MeS), however the 295 molecular evidence linking the two health conditions are lacking. Proteomics coupled with 296 protein-network analyses have emerged as powerful tools to predict disease-causing 297 genes/proteins, to reveal disease-related biomolecular subnetworks/pathways, and to develop 298 new criteria for disease classification. We used proteomics-based approach to identify the 299 molecular marker (if any) to explain the possible link between the history of miscarriage and 300 MeS. We also developed a protein-protein network to propose a hypothesis to predict the risk for onset of CVDs among women with history of miscarriage and MeS. We recruited women from a 302 Mendelian population of same gene pool so that the study restricts the influence of major confounders (genetic, dietary, cultural, and lifestyle) on proteomic analysis (Goh et al., 2007). Also, recruitment of naïve individuals who were not on medication/interventional drugs gives clear picture of the proteome profile in the selected groups. We report eighteen differentially regulated proteins among different case groups and showed strong interactions among TTR, TF, 307 ApoA1 and HP.

A dysregulation of proteins of signalling pathways and ion-transport indicate severe 309 physiological turbulence in the cases of a history of miscarriage (group D) and MeS (group C) alone. For example, in both groups C \& D, CRA_showed upregulation, and chain B transferrinbinding protein $\mathrm{B}$ and chain $\mathrm{A}$, serum transferrin showed down-regulation, while coiled-coil 312 domain protein showed downregulation in group D but upregulation in group C (Fig. 2). A dysregulation of proteins involved in ATP binding, signal transduction and iron transport in a 314 cell has also been reported in several metabolic and neurodegenerative disorders (Leitner \& 315 Connor, 2012; Zhao et al., 2015). Similar to our observations, among cases with miscarriage 316 history and/or MeS, ApoA1, HP, transferrin, fibrinogen, and transthyretin have also been 
317 reported in independent studies in humans or mouse models (Rangel-Zúñiga et al., 2015; Geyer

318 et al., 2016; Hsieh et al., 2016). Proteomics-based studies have also reported 2-14 proteins

319 associated with preeclampsia and pre-term birth (Law et al., 2005; Metwally et al., 2014),

320 however to the best of our knowledge, proteomic analyses of the subjects with recurrent

321 abortions are lacking. Metwally et al., (2014) reported HP and TTR as the key protein among

322 thirty-eight differentially expressed proteins explaining a link between recurrent miscarriages 323 and obesity.

324 Venn diagram suggested a common dysregulation of seven proteins in all the three case 325 groups (region V, Fig. 4). Increased expression of transferrin, HP protein (3 isoforms), SYNE 1, 326 serpin 38, and ApoA1 in groups A,C, \& D provide a better insights into the molecular link 327 between the history of miscarriage and MeS (Table 2). For example, HP also serves as an 328 important marker for adiposity and inflammatory conditions in human (Friedrichs et al., 1995; 329 Chiellini et al., 2004). Increased expression of HP in group A and C could be due to the presence 330 of MeS. However, in Group D women the increased expression of HP suggests that the 'stress 331 test' of a female during pregnancy (Allen, 2016) resulting in miscarriage may have left some 332 inflammatory signatures, where increasing expression of HP is one facet of it. However, the role 333 of haptoglobin gene polymorphism in better reproductive outcomes can also not be ignored 334 (Metwally et al., 2014).

Group C cases with a history of miscarriage showed ApoA1 as a group-specific protein (region I, Fig. 4). In women, the history of miscarriage has been implicated in atherosclerosis

337 (Sharma \& Gulati, 2013) which in turn is a result of endothelium damage in the arteries due to 338 cholesterol deposition (Nordestgaard \& Varbo, 2014). As ApoA1 binds with the lipid molecules,

339 specifically HDL-C (Marcovina \& Packard, 2006), the lower expression of ApoA1 results into 
340 the lower level of HDL-C (Davidson et al., 1996) leading to catastrophe in the lipid metabolic

341 pathway. The Group D women showed lower level of ApoA1 as compared with those with

342 absolute controls (Fig. 2), which is in concurrence of the findings of Fanshawe \& Ibrahim

343 (2013). As women with MeS show low levels of ApoA1 (Borja et al., 2017), therefore lowering

344 of ApoA1 isoforms in cases the history of miscarriage in our study imply a physiological

345 interaction among common proteins leading to common protein expression patterns in both the 346 diseases.

347 Transferrin, a carrier protein synthesized in the liver, acts as a prooxidant molecule as it 348 inhibits iron-dependent hydroxyl radical $\left(\mathrm{OH}^{\circ}\right)$ formation from $\mathrm{H}_{2} \mathrm{O}_{2}$ (Halliwel \& Gutteridge, 349 1989) and thus (Memişoğullarl \& Bakan, 2004). MeS, a metainflammation state, develops due to 350 metabolic-triggered inflammation (Monteiro \& Azevedo, 2010) causing oxidative stress 351 (Pasarica et al., 2009) and thus becomes deleterious for vascular functions (Esposito \& 352 Giugliano, 2004). Women with history of miscarriages and preterm births show high 353 inflammation (Stephenson, 2007; Bukowski et al., 2017). Therefore, an elevated level of 354 transferrin signifies a biological response to counteract inflammation. Similarly, serpin 38, 355 another anti-inflammatory molecule also showed an increased expression in three case groups 356 with an increasing pattern from absolute cases $>$ history of miscarriages $>$ MeS group.

358 both history of miscarriage and MeS may cause CVDs through independent pathways. PCA 359 analyses also support our views as two proteins dysregulated in region II (S1: chainB transferrin360 binding protein, S2: chainA transferrin) together form a distinct cluster (quadrant IV). Such 361 clustering may be the cause or an effect of the additional independent pathways operating in both 
362 the diseases, but this also suggests that the metabolic signatures of MeS may be common to the

363 history of miscarriage in women.

364 FGF and isoforms of FGG showed differential expression exclusively in MeS cases in 365 our study (region-III, Fig. 4A), which have also been implicated in CVDs. The patients of CVDs 366 show high levels of FGG. High level of FGG has been positively with traditional risk factors for 367 CVD (BMI, TG, fasting glucose) but has been negatively associated with HDL-C (Alexander, 368 2012). Clinicians have also suggested FGG as one of the target molecules to treat CVDs, 369 inflammation and thrombosis (Farrell, 2004). On the other hand, FGF possesses the angiogenic 370 capacity and shows an inverse relationship with the levels of BMI, TG, fasting glucose, etc., 371 suggesting the multiple metabolic roles of FGF (Domouzoglou et al., 2015; Nies et al., 2015).

372 FGF improves the metabolic profile (low glucose and improve serum lipids) and acts as anti373 thrombotic agent. Therefore, FGF expression is the counter-effect of an increase in FGG 374 expression. Further, the exclusive up-regulation of different chains of FGG (S5 and S6, except 375 S4), and FGF (S16) in women with only MeS in contrast with absolute cases suggests that the MeS which is developed independently of miscarriage history differ physiologically from the MeS which is associated with history of miscarriage.

Though the history of miscarriage and MeS serve as independent risk factors for CVDs, the present study showed higher expression of TTR exclusively among women with a history of miscarriage and MeS. Metwally et al., (2014) showed an increased expression of TTR in the endometrium of obese women with recurrent miscarriage and suggested an ongoing inflammatory reaction in endometrial lining of obese women may contribute to higher risk of miscarriage. So, increased expression of TTR among absolute cases may be the result of the interactions between the commonly dysregulated proteins in three metabolic states, specifically 
385 HP, TF, and ApoA1. Also, TTR increase has been implicated in glucose intolerance, obesity,

386 T2DM (Mody et al., 2008; Pandey et al., 2015), cardiomyopathy and is considered to be one of

387 the target molecules in the therapy of heart failure (Castano et al., 2015). Similarly, differential

388 levels of TTR in serum have been linked various inflammatory diseases including Alzheimer

389 (Velayudhan et al., 2012), osteoarthritis (Akasaki et al., 2015), breast cancer (Villanueva et al.,

390 2006; Römpp et al., 2007), ovarian cancer (Zhang et al., 2004) and hepatocellular carcinomas

391 (Feng et al., 2005). Protein-protein interaction analyses based on either eighteen dysregulated

392 proteins in all case groups or seven commonly dysregulated proteins in three metabolic cases

393 suggest that TTR interacts with HP, ApoA1, and TF and cross talk between HP, ApoA1, TF, and

394 TTR. To the best of our knowledge, present study indicates the role of TTR in metabolic

395 syndrome vis-à-vis miscarriage for the first time.

396

397 Strengths

398 The major strength of this study is a collection of samples from a single Mendelian population

sharing a common gene pool with a similar lifestyle, physical activity and dietary habits. Such a

400

retrospective study in a single population thereby reduces the effect of genomic variations,

401

dietary habits etc. in different ethnic groups on proteins to the maximum. In a hospital based

402 case-control study, such matching may not be possible. Since plasma proteome is largely

403

affected by intervention through drugs, insights into the pathways may be obtained through the

404

recruitment of participants who are not under the influence of medication. Therefore, another

405

major strength of the study is the recruitment of naïve participants who were not on any

drug/medical prescription. The study also involved precise phenotyping by cross-validation of

407

reproductive history through repeated multiple-questions involving 'miscarriage'. 


\section{SUMMARY}

410 Absolute case group (women with a history of miscarriage and MeS) showed altered peripheral

411 blood proteome with an increased expression of transthyretin (TTR). In contrast, haptoglobin 412 (HP) and transferrin (TF) showed upregulation and ApoA1 showed downregulation in the three 413 case groups. Networking analyses suggest cross talk between the four dysregulated proteins i.e. 414 HP, TF, ApoA1, and TTR as a connecting link between miscarriage history and MeS. We 415 propose the putative role of TTR in an increased risk of metabolic adversities among women 416 with miscarriages and MeS. However, longitudinal follow-up studies with larger sample sizes 417 would further help to demonstrate the involvement of TTR and significance of its cross-talk with 418 other proteins in the occurrence of CVDs in women with a history of miscarriages and MeS.

\section{ACKNOWLEDGMENTS}

421 The authors thank Prof. P.K. Ghosh and Prof. V.R. Rao for their valuable, timely inputs 422 throughout the completion of the DBT funded project. The authors also acknowledge Dr 423 Priyanka Rani Garg and Shipra Joshi for their help during the fieldwork.

\section{References}

427 1. Akasaki Y, Reixach N, Matsuzaki T, Alvarez-Garcia O, Olmer M, Iwamoto Y, Buxbaum $428 \quad \mathrm{~N}$, Lotz MK (2015). Transthyretin deposition in articular cartilage: a novel mechanism in 429 the pathogenesis of osteoarthritis. Arthritis \& Rheumatology. 67(8): 2097-2107 DOI: 430 10.1002/art.39178. 
431 2. Alexander KS (2012). Characterization of [gamma]'fibrinogen as a cardiovascular risk 432 marker. Doctoral Thesis, Oregon Health \& Science University. Available from: 433 http://digitalcommons.ohsu.edu/cgi/viewcontent.cgi?article=1866\& context=etd

434 3. Allen RH (2016). Is there a link between miscarriage and future cardiovascular disease? Ob/gyn Clinical Alert. 32:78-79.

4. Bag AK, Saha S, Sundar S, Saha B, Chakrabarti A, Mandal C (2014). Comparative proteomics and glycoproteomics of plasma proteins in Indian visceral leishmaniasis. Proteome Science. 22:12(1):48 DOI 10.1186/s12953-014-0048-z

5. Biswas S, Sharma S, Saroha A, Bhakuni DS, Malhotra R, Zahur M, Oellerich M, Das HR, Asif AR (2013). Identification of novel autoantigen in the synovial fluid of rheumatoid

6. Bradford MM (1976). A rapid and sensitive method for the quantitation of microgram arthritis patients using an immunoproteomics approach. PLoS ONE. 8:e56246 DOI

7. Bukowski R, Sadovsky Y, Goodarzi H, Zhang H, Biggio JR, Varner M, Parry S, Xiao F, Esplin SM, Andrews W, Saade GR. 2017. Onset of human preterm and term birth is related to unique inflammatory transcriptome profiles at the maternal fetal interface. PeerJ. 5:e3685

8. Castano A, Narotsky D, Maurer MS (2015). American College of Cardiology. Available from http://www.acc.org/latest-in-cardiology/articles/2015/10/13/08/35/emerging-therapiesfor-transthyretin-cardiac-amyloidosis (accessed on 15 January 2017). 
453 9. Chiellini C, Santini F, Marsili A, Berti P, Bertacca A, Pelosini C, Scartabelli G, Pardini E, 454 López-Soriano J, Centoni R, Ciccarone AM, Benzi L, Vitti P, Del Prato S, Pinchera A, 455 Maffei M (2004). Serum haptoglobin: a novel marker of adiposity in humans. The Journal 456 of Clinical Endocrinology \& Metabolism. 89(6):2678-83 DOI 0.1210/jc.2003-031965.

457

458

459

460

461

462

463

464

465

466

467

468

469

470

471

472

473

474

10. Davidson WS, Hazlett T, Mantulin WW, Jonas A (1996). The role of apolipoprotein A1 domains in lipid binding. Proceedings of the National Academy of Sciences. 93:1360513610 DOI 10.1073/pnas.93.24.13605.

11. Domouzoglou EM, Naka KK, Vlahos AP, Papafaklis MI, Michalis LK, Tsatsoulis A, Maratos-Flier E. 2015. Fibroblast growth factors in cardiovascular disease: The emerging role of FGF21. American Journal of Physiology-Heart and Circulatory Physiology. 309:H1029-H1038 DOI 10.1152/ajpheart.00527.2015

12. Esposito K, Giugliano D. 2004. The metabolic syndrome and inflammation: association or causation? Nutrition, Metabolism and Cardiovascular Diseases. 14(5):228-32 DOI 10.1016/S0939-4753(04)80048-6.

13. Fanshawe AE, Ibrahim M. 2013. The current status of lipoprotein (a) in pregnancy: A literature review. Journal of cardiology. 61(2):99-106 DOI 10.1016/j.jjcc.2012.09.009.

14. Farrell DH. 2004. Pathophysiologic roles of the fibrinogen gamma chain. Current opinion in hematology. 11:151-155 DOI 10.1097/01.moh.0000131440.02397.a4

15. Feng JT, Liu YK, Song HY, Dai Z, Qin LX, Almofti MR, Fang CY, Lu HJ, Yang PY, Tang ZY. 2005. Heat-shock protein 27: A potential biomarker for hepatocellular carcinoma identified by serum proteome analysis. Proteomics. 5(17): 4581-4588 DOI 10.1002/pmic.200401309. 
475 16. Fraser A, Nelson SM, Macdonald-Wallis C, Cherry L, Butler E, Sattar N, Lawlor DA. 2012. 476 Associations of pregnancy complications with calculated CVD risk and cardiovascular risk 477 factors in middle age: the Avon Longitudinal Study of Parents and Children. Circulation. 478 125(11):1367-80 DOI 10.1161/CIRCULATIONAHA.111.044784.

479 480

17. Friedrichs WE, Navarijoashbaugh AL, Bowman BH, Yang F. 1995. Expression and inflammatory regulation of haptoglobin gene in adipocytes. Biochemical and biophysical research communications. 209(1):250-6 DOI 10.1006/bbrc.1995.1496.

18. Germain AM, Romanik MC, Guerra I, Solari S, Reyes MS, Johnson RJ, Price K, Karumanchi SA, Valdés G. 2007. Endothelial dysfunction a link among preeclampsia, recurrent pregnancy loss, and future cardiovascular events? Hypertension. 49: 90-95 DOI 10.1161/01.HYP.0000251522.18094.d4.

19. Geyer PE, Albrechtsen NJW, Tyanova S, Grassl N, Iepsen EW, Lundgren J, Madsbad S, Holst JJ, Torekov SS, Mann M. 2016. Proteomics reveals the effects of sustained weight loss on the human plasma proteome. Molecular systems biology. 12(12): 901 DOI $10.15252 / \mathrm{msb} .20167357$.

20. Goh KI, Cusick ME, Valle D, Childs B, Vidal M, Barabási AL. 2007. The human disease network. Proceedings of the National Academy of Sciences. 104(21):8685-8690 DOI 10.1073/pnas.0701361104.

21. Grundy SM. 2005. A constellation of complications: the metabolic syndrome. Clinical Cornerstone. 7(2-3):36-45 DOI 10.1016/S1098-3597(05)80066-3.

22. Gu D, Reynolds K, Wu X, Chen J, Duan X, Reynolds RF, Whelton PK, He J; InterASIA Collaborative Group. 2005. Prevalence of the metabolic syndrome and overweight among adults in China. The Lancet. 365(9468):1398-1405 DOI 10.1016/S0140-6736(05)66375-1. 
498 23. Halliwel B, Gutteridge JMC. 1989. Free radicals in biology and medicine. Oxford: $499 \quad$ Clarendon Press.

500 24. Hsieh CC, Liao CC, Liao YC, Hwang LS, Wu LY, Hsieh SC. 2016. Proteomic changes 501 associated with metabolic syndrome in a fructose-fed rat model. Journal of food and drug 502 analysis. 24(4):754-761 DOI 10.1016/j.jfda.2016.03.005.

503 25. Kharazmi E, Dossus L, Rohrmann S, Kaaks R. 2011. Pregnancy loss and risk of 504 cardiovascular disease: a prospective population-based cohort study (EPIC-Heidelberg). Heart. 97(1):49-54 DOI 10.1136/hrt.2010.202226.

506

507

508

509

510

511

512

513

514

515

516

517

518

26. Law KP, Han TL, Tong C, Baker PN. 2005. Mass spectrometry-based proteomics for preeclampsia and preterm birth. International journal of molecular sciences. 16(5), 1095210985 DOI 10.3390/ijms160510952.

27. Leitner DF, Connor JR. 2012. Functional roles of transferrin in the brain. Biochimica et $\begin{array}{lllll}\text { Biophysica Acta } \quad \text { (BBA)-General Subjects. } & \mathbf{1 8 2 0 ( 3 )} \text { :393-402 DOI }\end{array}$ 10.1016/j.bbagen.2011.10.016.

28. Lim S, Shin H, Song JH, Kwak SH, Kang SM, Yoon JW, Choi SH, Cho SI, Park KS, Lee HK, Jang HC, Koh KK. 2011. Increasing prevalence of metabolic syndrome in Korea: the Korean National Health and Nutrition Examination Survey for 1998-2007. Diabetes care. 34(6):1323-1328 DOI 10.2337/dc10-2109.

29. Maino A, Siegerink B, Algra A, Martinelli I, Peyvandi F, Rosendaal FR. 2016. Pregnancy loss and risk of ischaemic stroke and myocardial infarction. British journal of haematology. 174(2):302-9 DOI 10.1111/bjh.14043. 
519 30. Marcovina S, Packard CJ. 2006. Measurement and meaning of apolipoprotein AI and

520 apolipoprotein B plasma levels. Journal of internal medicine. 259(5):437-46 DOI 10.1111/j.1365-2796.2006.01648.x

522 31. McDonald SD, Malinowski A, Zhou Q, Yusuf S, Devereaux PJ. 2008. Cardiovascular 523 sequelae of preeclampsia/eclampsia: a systematic review and meta-analyses. American heart journal. 156(5):918-30 DOI 10.1016/j.ahj.2008.06.042.

32. Memişoğulları R, Bakan E. 2004. Levels of ceruloplasmin, transferrin, and lipid peroxidation in the serum of patients with Type 2 diabetes mellitus. Journal of diabetes and its complications. 18(4):193-7 DOI 10.1016/S1056-8727(03)00032-1.

33. Metwally M, Preece R, Thomas J, Ledger W, Li TC. 2014. A proteomic analysis of the endometrium in obese and overweight women with recurrent miscarriage: preliminary evidence for an endometrial defect. Reproductive Biology and Endocrinology. 12:75 DOI 10.1186/1477-7827-12-75.

34. Mishra R, Sharma S, Sharma RS, Singh S, Sardesai MM, Sharma S, Mishra, V. 2018.

35. Mody N, Graham TE, Tsuji Y, Yang Q, Kahn BB. 2008. Decreased clearance of serum retinol-binding protein and elevated levels of transthyretin in insulin-resistant ob/ob mice. American Journal of Physiology-Endocrinology and Metabolism. 294(4): E785-E793 DOI

36. Monteiro R, Azevedo I. 2010. Chronic inflammation in obesity and the metabolic syndrome. Mediators of inflammation. 289645 DOI 10.1155/2010/289645. 
542 37. Nies VJ, Sanca G, Liu W, van Zutphen T, Struik D, Yu RT, Atkins AR, Evans RM, Jonker

543 JW, Downes MR. 2015. Fibroblast growth factor signaling in metabolic regulation.

$544 \quad$ Frontiers in endocrinology. 6:193 DOI 10.3389/fendo.2015.00193

545 38. Nordestgaard BG, Varbo A. 2014. Triglycerides and cardiovascular disease. The Lancet. 384(9943):626-35 DOI 10.1016/S0140-6736(14)61177-6.

39. Oliver-Williams CT, Heydon EE, Smith GC, Wood AM. 2013. Miscarriage and future maternal cardiovascular disease: a systematic review and meta-analysis. Heart. 99(22): 1636-1644 DOI 10.1136/heartjnl-2012-303237.

550

551

552

553

554

555

556

557

558

559

560

561

562

40. Pandey GK, Balasubramanyam J, Balakumar M, Deepa M, Anjana RM, Abhijit S, Kaviya A, Velmurugan K, Miranda P, Balasubramanyam M, Mohan V, Gokulakrishnan K. 2015. Altered circulating levels of retinol binding protein 4 and transthyretin in relation to insulin resistance, obesity, and glucose intolerance in Asian Indians. Endocrine Practice. 21(8): 861-869 DOI 10.4158/EP14558.

41. Parker DR, Lu B, Sands-Lincoln M, Kroenke CH, Lee CC, O’Sullivan M, Park HL, Parikh N, Schenken RS, Eaton CB. 2014. Risk of cardiovascular disease among postmenopausal women with prior pregnancy loss: the women's health initiative. The Annals of Family Medicine. 12(4):302-9 DOI 10.1370/afm.1668.

42. Pasarica M, Sereda OR, Redman LM, Albarado DC, Hymel DT, Roan LE, Rood JC, Burk DH, Smith SR. 2009. Reduced adipose tissue oxygenation in human obesity: evidence for rarefaction, macrophage chemotaxis, and inflammation without an angiogenic response. Diabetes. 58(3):718-25 DOI 10.2337/db08-1098 
563 43. Ranasinghe P, Mathangasinghe Y, Jayawardena R, Hills AP, Misra A. 2017. Prevalence and

564 trends of metabolic syndrome among adults in the asia-pacific region: a systematic review.

565 BMC public health. 17(1):101 DOI 10.1186/s12889-017-4041-1.

566 44. Rangel-Zúñiga OA, Camargo A, Marin C, Peña-Orihuela P, Pérez-Martínez P, Delgado-

567 Lista J, González-Guardia L, Yubero-Serrano EM, Tinahones FJ, Malagón MM, Pérez-

568 Jiménez F, Roche HM, López-Miranda J. 2015. Proteome from patients with metabolic

569 syndrome is regulated by quantity and quality of dietary lipids. BMC genomics. 16:509 DOI

$570 \quad 10.1186 / \mathrm{s} 12864-015-1725-8$.

571 45. Ranthe MF, Andersen EAW, Wohlfarht J, Bundgaard H, Melbye M, Boyd HA. 2013.

572 Pregnancy loss and later risk of atherosclerotic disease. Circulation. 127(17):1775-82 DOI

$573 \quad$ 10.1161/CIRCULATIONAHA.112.000285.

574 46. Römpp A, Dekker L, Taban I, Jenster G, Boogerd W, Bonfrer H, Spengler B, Heeren R,

575 Smitt PS, Luider TM. 2007. Identification of leptomeningeal metastasis-related proteins in

576 cerebrospinal fluid of patients with breast cancer by a combination of MALDI-TOF,

577 MALDI-FTICR and nanoLC-FTICR MS. Proteomics. 7(3):474-481 DOI

$578 \quad 10.1002 /$ pmic. 200600719 .

579 47. Saroha A, Kumar S, Chatterjee BP, Das HR. 2012. Jacalin bound plasma Oglycoproteome 580 and reduced sialylation of alpha 2-HS glycoprotein in rheumatoid arthritis patients. PLoS ONE. 7:e46374 DOI 10.1371/journal.pone.0046374.

582 48. Sharma K, Gulati M. 2013. Coronary artery disease in women: A 2013 update. Global 583 Heart. 8(2):105-112 DOI 10.1016/j.gheart.2013.02.001.

49. Stephenson J. 2007. Miscarriage and Inflammation. JAMA. 297(7):686 DOI 585 10.1001/jama.297.7.686-b. 
586 50. Velayudhan L, Killick R, Hye A, Kinsey A, Güntert A, Lynham S, Ward M, Leung R,

587 Lourdusamy A, To AW, Powell J, Lovestone S. 2012. Plasma transthyretin as a candidate 588 marker for Alzheimer's disease. Journal of Alzheimer's Disease. 28(2): 369-375 DOI $589 \quad$ 10.3233/JAD-2011-110611.

590 51. Villanueva J, Shaffer DR, Philip J, Chaparro CA, Erdjument-Bromage H, Olshen AB, 591 Fleisher M, Lilja H, Brogi E, Boyd J, Sanchez-Carbayo M, Holland EC, Cordon-Cardo C, 592 Scher HI, Tempst P. 2006. Differential exoprotease activities confer tumor-specific serum 593 peptidome patterns. The Journal of clinical investigation. 116(1): 271-284 DOI 594

52. Wang J, Zhou N, Xu B, Hao H, Kang L, Zheng Y, Jiang Y, Jiang H. 2012. Identification 596 and cluster analysis of streptococcus pyogenes by MALDI-TOF Mass Spectrometry. PLoS

53. Xi B, He D, Hu Y, Zhou D. 2013. Prevalence of metabolic syndrome and its influencing 599 factors among the Chinese adults: the China Health and Nutrition Survey in 2009. Preventive medicine. 57(6):867-871 DOI 10.1016/j.ypmed.2013.09.023.

601

54. Xu B, Zhang J, Xu Y, Lu J, Xu M, Chen Y, Bi Y, Ning, G. 2013. Association between 602 history of abortion and metabolic syndrome in middle-aged and elderly Chinese women. Frontiers of medicine, 7(1):132-137 DOI 10.1007/s11684-013-0250-x

55. Yeh CJ, Chang HY, Pan WH. 2011. Time trend of obesity, the metabolic syndrome and 605 related dietary pattern in Taiwan: from NAHSIT 1993-1996 to NAHSIT 2005-2008. Asia 606 Pacific journal of clinical nutrition. 20(2):292-300 DOI 10.6133/apjen.2011.20.2.19.

56. Zhang Z, Bast RC, Yu Y, Li J, Sokoll LJ, Rai AJ, Rosenzweig JM, Cameron B, Wang YY, 608 Meng XY, Berchuck A, Van Haaften-Day C, Hacker NF, de Bruijn HW, van der Zee AG, 
609 Jacobs IJ, Fung ET, Chan DW. 2004. Three biomarkers identified from serum proteomic 610 analysis for the detection of early stage ovarian cancer. Cancer Research. 64(16): 5882$611 \quad 5890$ DOI 10.1158/0008-5472.CAN-04-0746.

612 57. Zhao HQ, Wu H, Meng R, Du S, Tao SJ. 2015. Distribution of serum transferrin, and its 613 associations with metabolic disorders among Chinese: A nation-wide, health and nutrition 614 survey. Molecular nutrition \& food research. 59(8):1535-40 DOI $615 \quad 10.1002 / \mathrm{mnfr} .201500038$.

616

617 


\section{Figure 1}

Comparative 2-DE analysis of plasma proteins.

Silver stained 2-Dimensional gel electrophoretic profile of plasma proteins from four different groups [A: absolute cases with the history of miscarriage and metabolic syndrome (MeS) (Gr A); B: absolute controls without history of miscarriage and MeS ( $\operatorname{~r~B);~C:~MeS~alone~(~} \operatorname{Gr} C)$; and D: history of miscarriage alone (Gr D)]. Please note the differential expression of eighteen proteins among absolute cases, history of miscarriage, MeS and comparing with absolute controls. An equal amount $(50 \mu \mathrm{g})$ of plasma proteins were separated by $4-7 \mathrm{pH}$ range IPG strip $(7 \mathrm{~cm})$ followed by SDS-PAGE (12\%) and silver stained. Differentially expressed protein spots were marked with numbers.

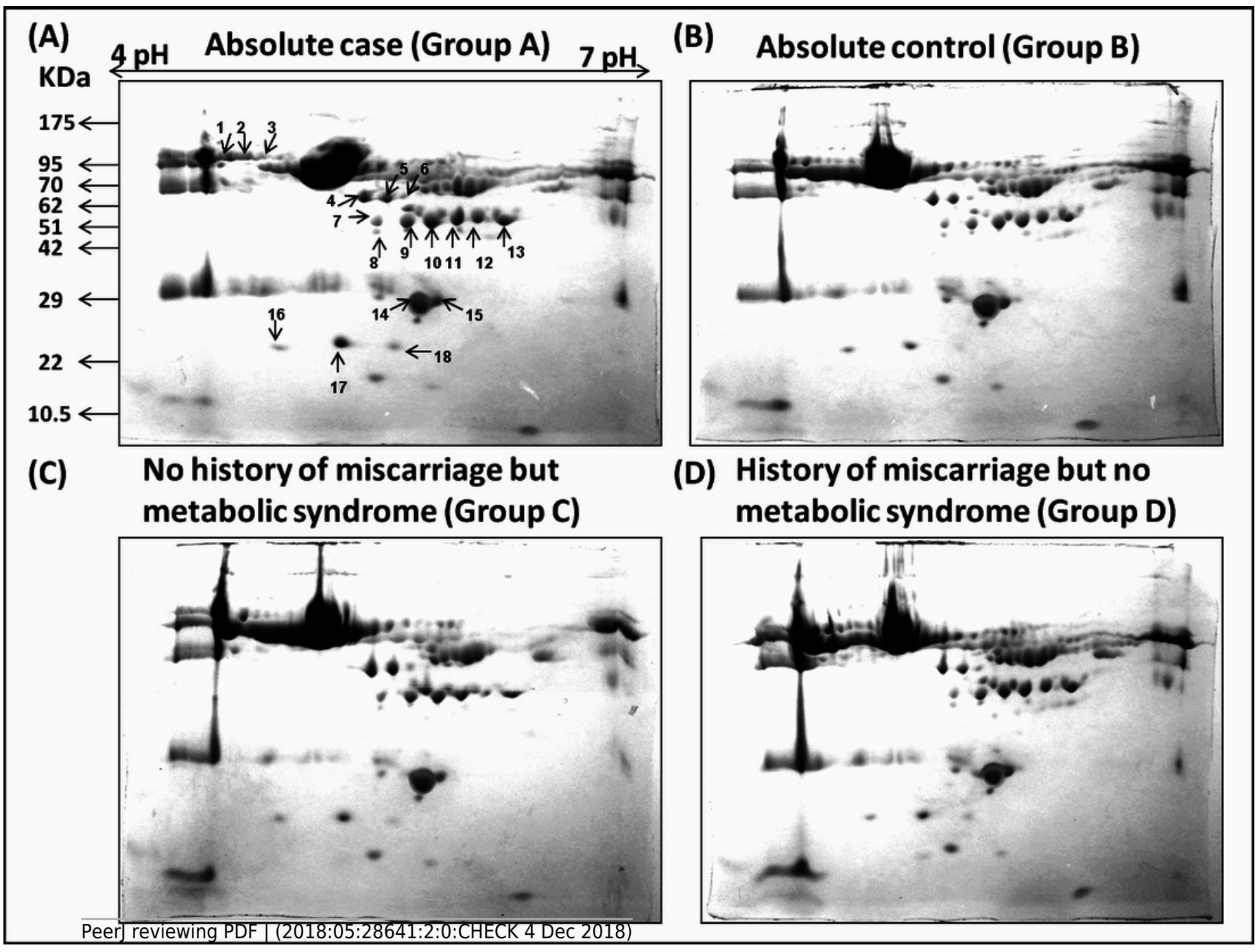




\section{Figure 2}

Cluster analysis based on expression patterns of the eighteen differentially expressed proteins.

(A) The SOTA cluster tree illustrates differential expression of proteins in case groups. (B) The eighteen differentially expressed proteins were grouped into five clusters based on their expression profiles. The mean of expression profile is marked in pink for each cluster, whereas expression profile of each individual protein in the cluster is represented by gray lines. Gr A represents absolute cases, Gr C represents metabolic syndrome, and Gr D represents the history of miscarriage.

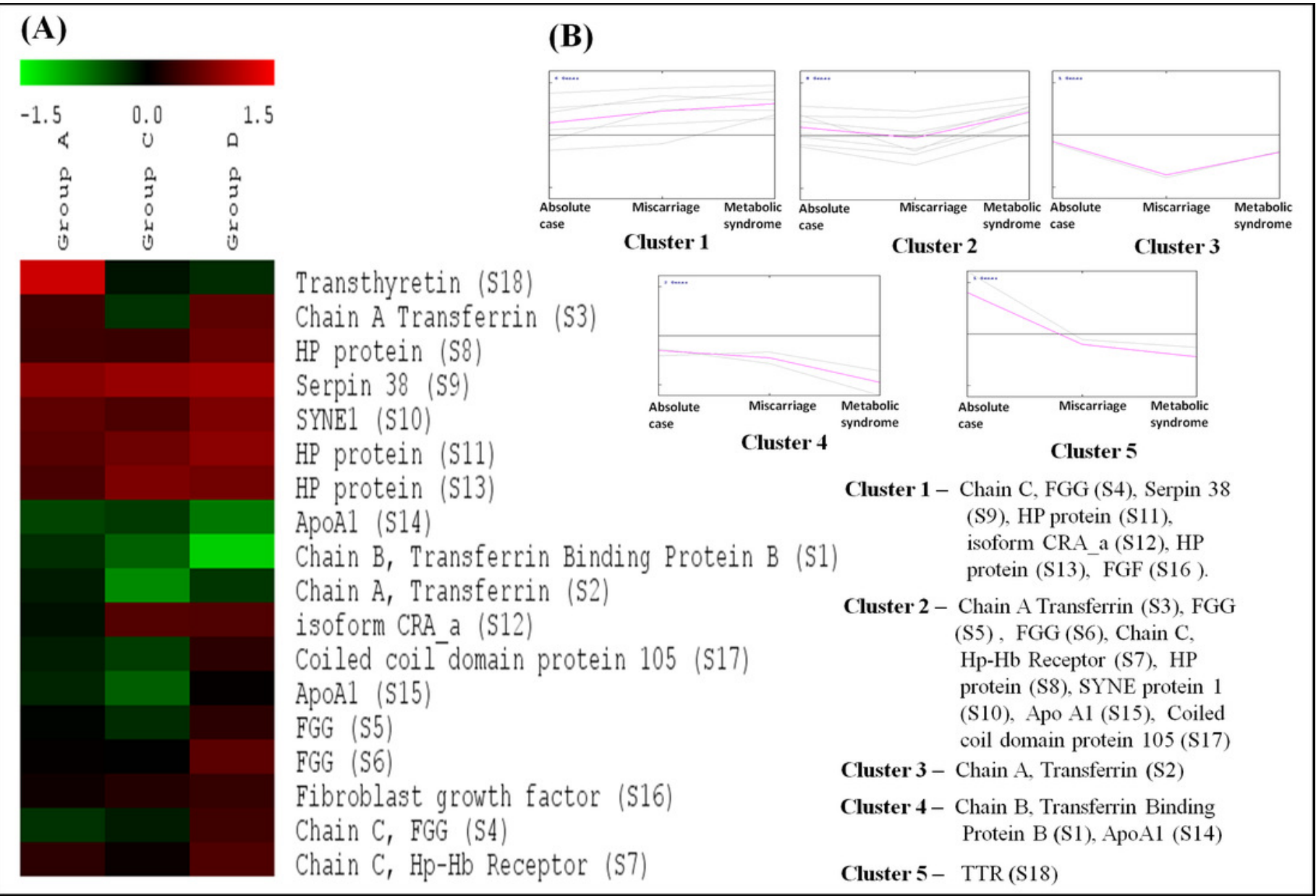


Figure 3

\section{Functional classification of differentially expressed proteins identified in three case} groups.

(A) The biological processes, (B) molecular functions and (C) cellular components regulated by differentially expressed proteins by Gene Ontology search.

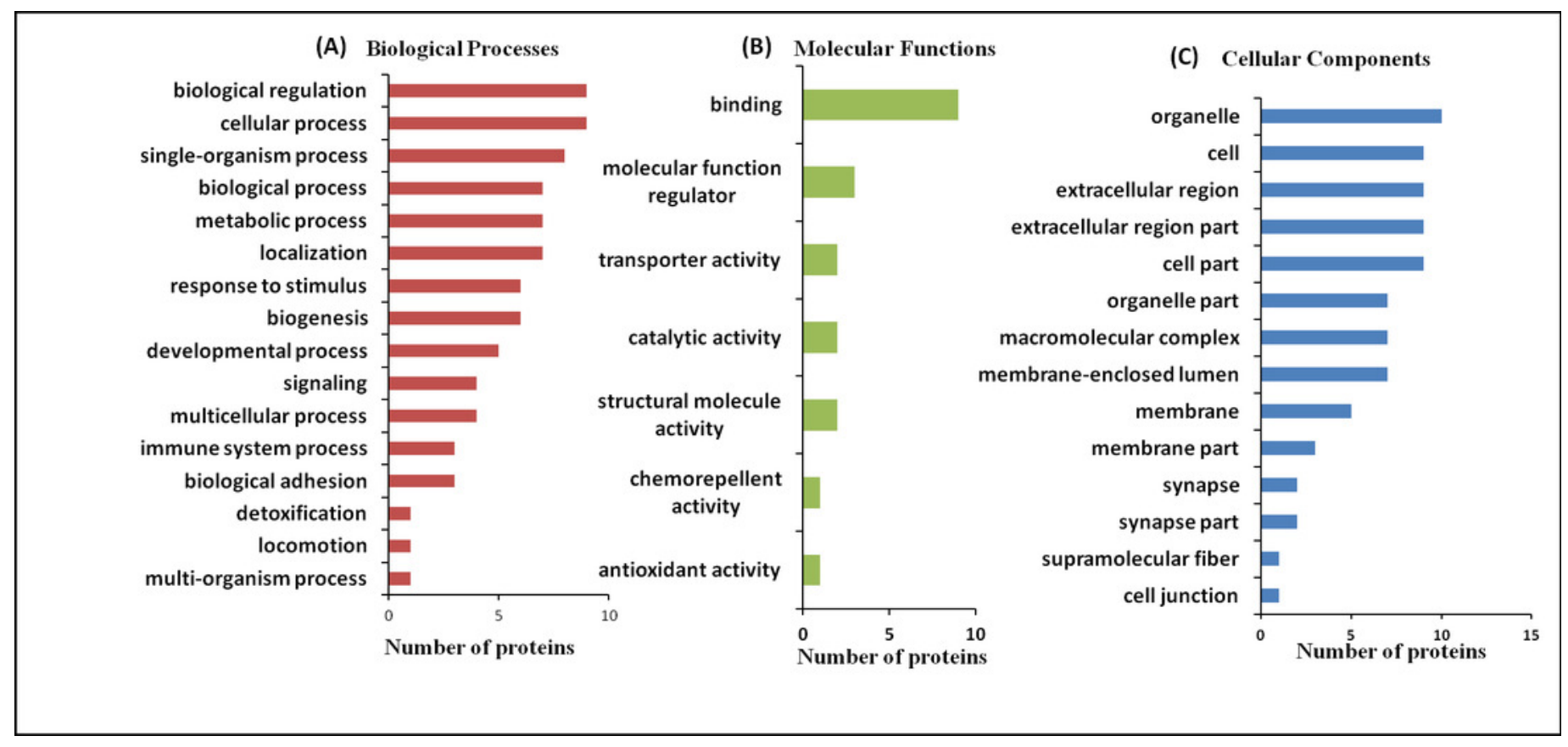




\section{Figure 4}

Venn diagram and PCA analysis of differentially expressed proteins.

(A) Venn diagram showing the distribution of differential expressed proteins among the three case groups. Region $V$ shows seven proteins (transferrin, 3 different forms of HP proteins, SYNE protein 1, serpin38, apoA1) commonly dysregulated th the intersection of three case groups; Region VII shows exclusive dysregulation of TTR in absolute cases; Region II shows four proteins (chain B transferring binding protein, transferring, CRA_a; coiled coil domain) commonly dysregulated at the intersection of cases with miscarriage history, and with MeS;

(B) Number of differentially expressed proteins in different pathophysiological states; (C) PCA biplots based on differentially expressed proteins in all three case groups. Protein expressed in the only absolute cases was represented by a red dot in scatter plot whereas green, yellow, pink, grey and blue dots belonged to patients having miscarriages + MeS, only MeS, absolute case + MeS, only miscarriages and all four groups respectively. 
(A)

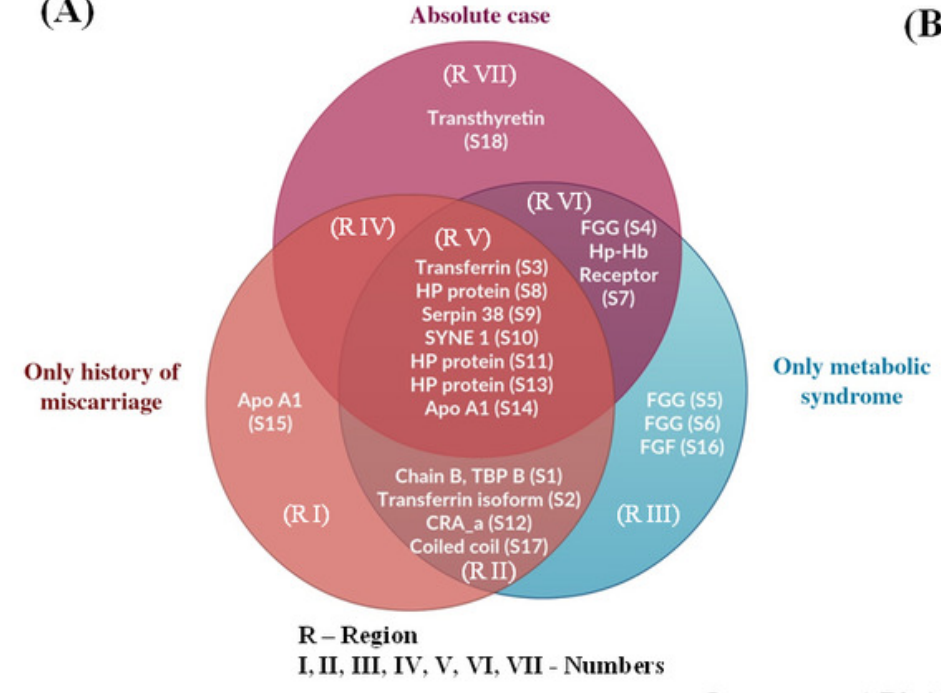

(B)

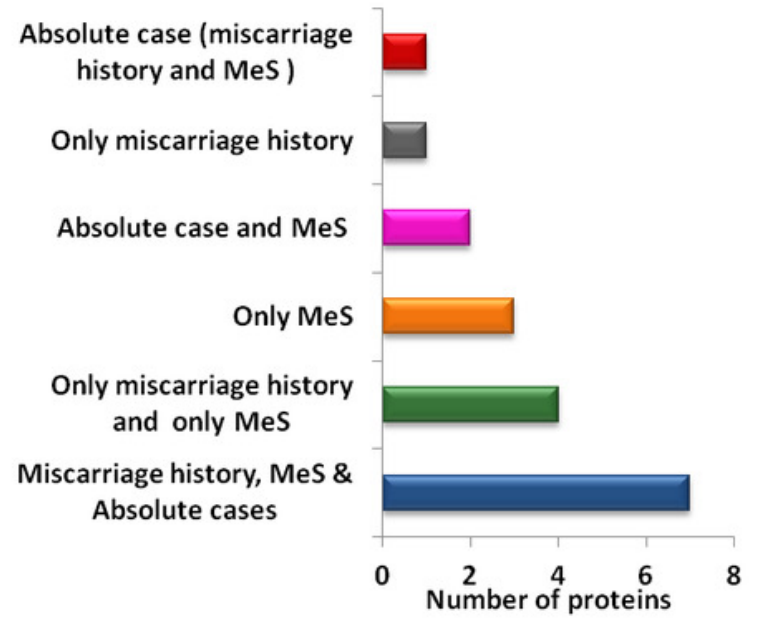

Component Plot in Rotated Space

(C)

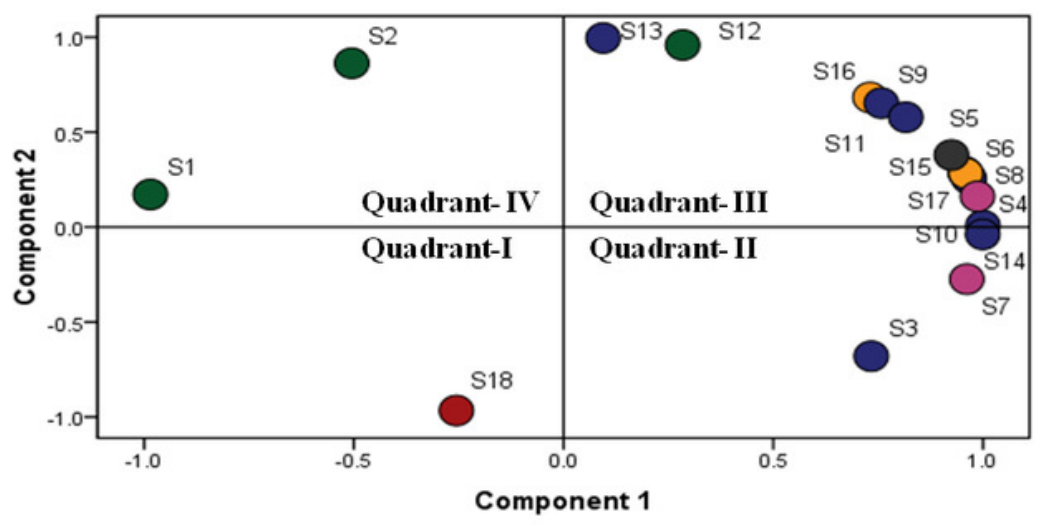


Figure 5

Protein-protein interaction network based on STRING analysis.

The protein-protein interactions among eighteen differentially expressed proteins identified in the present study (A), and seven proteins commonly dysregulated in three case groups and TTR (B). The protein-protein interactions with confidence score $>0.700$ were considered.

(A)

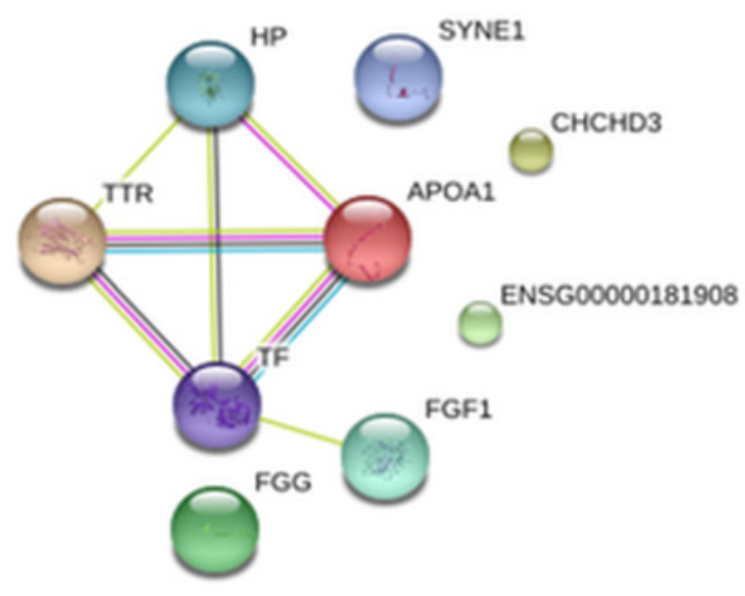

Known Interactions

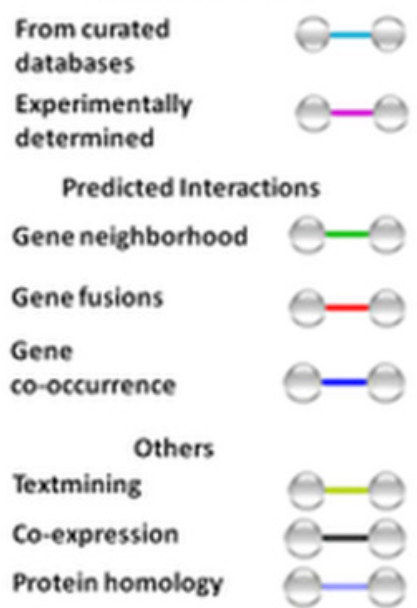

(B)

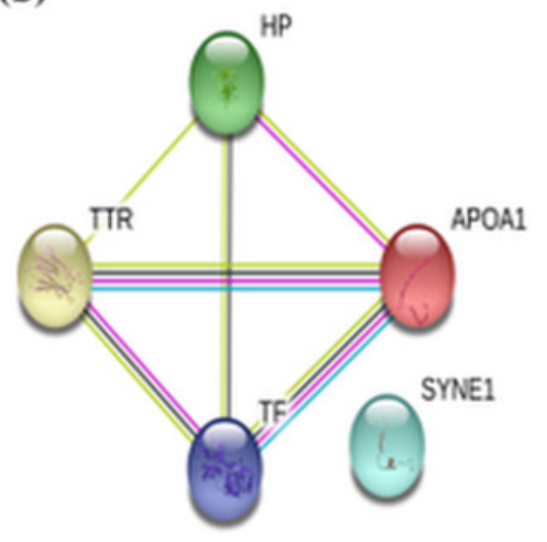




\section{Figure 6}

Validation of expression of TTR in three case groups using Western blot analysis and ELISA.

$(A \& B)$ The Western blots analysis revealed 1.56, 1.33 and 2.21 fold higher expression of TTR in absolute cases as compared to absolute controls $(p<0.001)$, only MeS $(p<0.03)$ and only history of miscarriage $(p<0.002)$, respectively. (C) ELISA analysis of TTR showed 2.50, 2.23 and 4.10 fold elevated expression in absolute cases $(n=20)$ as compared to absolute control $(p<0.0001, n=20)$, only metabolic syndrome $(p<0.0001, n=20)$ and only miscarriages $(p<0.0001, n=20)$ respectively. ' ${ }^{\prime}$ ' denotes significant difference in absolute cases as compared to absolute controls, only MeS and only history of miscarriage in Independent t-test.

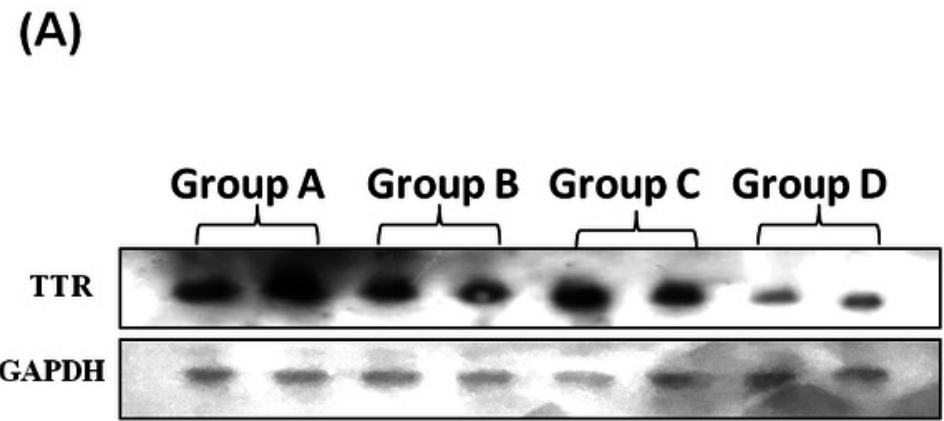

(C)

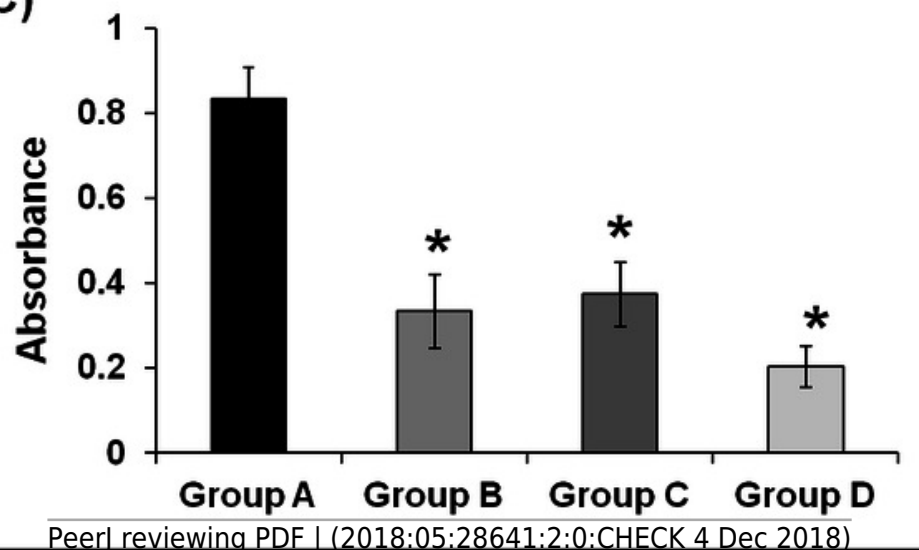

(B)

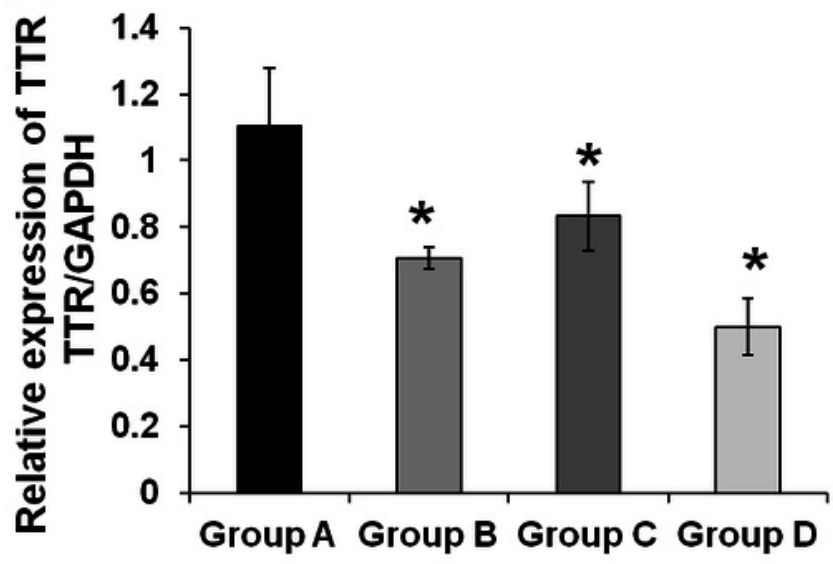

Group A - Absolute cases

Group B - Absolute controls

Group C - No history of miscarriage but metabolic syndrome

Group D - History of miscarriage but no metabolic syndrome 
Table $\mathbf{1}$ (on next page)

Details of differentially expressed proteins identified by MALDI-TOF/MS-MS. 
1 Table 1: Details of differentially expressed proteins identified by MALDI-TOF/MS-MS.

\begin{tabular}{|c|c|c|c|c|c|}
\hline $\begin{array}{l}\text { Spot } \\
\text { No. }\end{array}$ & $\begin{array}{c}\text { Accession } \\
\text { number }\end{array}$ & Protein name & $\begin{array}{c}\text { MOWSE } \\
\text { Score }\end{array}$ & $\begin{array}{c}\text { M.W. (Da)/ } \\
\text { PI calculated }\end{array}$ & $\begin{array}{l}\text { Peptide } \\
\text { matched }\end{array}$ \\
\hline \multirow[t]{2}{*}{1} & gi|377656487 & Chain B, Transferrin-Binding & 173 & $77301 /$ & 29 \\
\hline & & Protein B & & 6.29 & \\
\hline 2 & gi|380258836 & Chain A, serum Transferrin & 141 & $77299 / 6.29$ & 21 \\
\hline 3 & gi|110590599 & Transferrin & 60 & $76988 / 6.29$ & 15 \\
\hline \multirow[t]{2}{*}{4} & gi|256032689 & Chain C, Recombinant & 51 & $35511 /$ & 17 \\
\hline & & Gamma Fibrinogen & & 5.2 & \\
\hline 5 & gi|119625326 & Fibrinogen gamma chain & 148 & $47971 / 5.2$ & 29 \\
\hline 6 & gi| 223170 & fibrinogen gamma & 132 & $46823 / 5.2$ & 14 \\
\hline \multirow[t]{2}{*}{7} & gi|764091351 & Chain C, Haptoglobin- & 114 & $29079 /$ & 15 \\
\hline & & haemoglobin Receptor & & 5.85 & \\
\hline 8 & gi|47124562 & HP protein & 92 & $31647 / 7.55$ & 20 \\
\hline 9 & gi|73623033 & Serpin 38 isoform b & 52 & $27940 / 5.28$ & 12 \\
\hline \multirow[t]{2}{*}{10} & gi|6330957 & Synaptic nuclear envelope & 49 & $15745 /$ & 35 \\
\hline & & protein 1 & & 5.1 & \\
\hline 11 & gi|47124562 & HP protein & 69 & $31647 / 7.55$ & 15 \\
\hline 12 & gi|119600328 & Isoform CRA_a & 54 & $5141 / 5.32$ & 8 \\
\hline 13 & gi|78174390 & HP protein & 94 & $38868 / 6.13$ & 18 \\
\hline 14 & gi|90108664 & Human Apolipoprotein A1 & 219 & $28061 / 5.56$ & 37 \\
\hline 15 & gi|90108664 & Human Apolipoprotein A1 & 100 & $28061 / 5.56$ & 29 \\
\hline 16 & gi|2979530 & Fibroblast growth factor & 50 & $14685 / 11.45$ & 9 \\
\hline \multirow[t]{2}{*}{17} & gi|226492892 & Coiled-coil domain-containing & 52 & $57386 /$ & 19 \\
\hline & & protein 105 & & 9.12 & \\
\hline 18 & gi|2098257 & Transthyretin & 126 & $13886 / 5.49$ & 13 \\
\hline
\end{tabular}

2 M.W. - Molecular weight, HP - Haptoglobin, PI - Isoelectric point 
Table 2 (on next page)

Differential expression (fold change) of the identified proteins in three case groups (group $\mathrm{A}, \mathrm{C}$ and $\mathrm{D}$ ) in comparison to the absolute controls (group B). 
1 Table 2: Differential expression (fold change) of the identified proteins in three case groups

2 (group A, C and D) in comparison to the absolute controls (group B).

\begin{tabular}{|c|c|c|c|c|c|}
\hline $\begin{array}{l}\text { Protein } \\
\text { spots }\end{array}$ & Protein names & $\begin{array}{c}\text { Absolute } \\
\text { case } \\
\text { (Group A) } \\
\text { Fold change }\end{array}$ & $\begin{array}{c}\text { Metabolic } \\
\text { syndrome } \\
\text { (Group C) } \\
\text { Fold change }\end{array}$ & $\begin{array}{c}\text { History of } \\
\text { Miscarriage } \\
\text { (Group D) } \\
\text { Fold change }\end{array}$ & P-value \\
\hline S1 & $\begin{array}{c}\text { Chain B, Transferrin } \\
\text { Binding Protein B }\end{array}$ & - & -2.32 & -1.48 & 0.651 \\
\hline S2 & Chain A, serum Transferrin & - & -1.24 & -1.76 & 0.721 \\
\hline S3 & Transferrin & 1.31 & 1.47 & -1.22 & 0.653 \\
\hline S4 & $\begin{array}{c}\text { Chain C, Recombinant } \\
\text { Gamma N308k Fibrinogen }\end{array}$ & -1.22 & 1.58 & - & 0.464 \\
\hline S5 & $\begin{array}{c}\text { Fibrinogen gamma chain, } \\
\text { isoform CRA_o }\end{array}$ & - & - & - & 0.767 \\
\hline S6 & fibrinogen gamma & - & 1.45 & - & 0.079 \\
\hline S7 & $\begin{array}{l}\text { Chain C, Haptoglobin- } \\
\text { haemoglobin Receptor }\end{array}$ & 1.2 & 1.38 & - & 0.641 \\
\hline S8 & HP protein & 1.29 & 1.53 & 1.26 & 0.315 \\
\hline S9 & Serpin 38 isoform b & 1.74 & 1.93 & 1.86 & 0.081 \\
\hline S10 & $\begin{array}{l}\text { Synaptic nuclear envelope } \\
\text { protein } 1\end{array}$ & 1.47 & 1.66 & 1.37 & 0.229 \\
\hline S11 & HP protein & 1.43 & 1.77 & 1.56 & 0.101 \\
\hline S12 & Isoform CRA_a & - & 1.39 & 1.41 & 0.425 \\
\hline S13 & HP protein & 1.35 & & 1.68 & 0.433 \\
\hline S14 & Human Apolipoprotein A-1 & -1.32 & -1.64 & - & 0.968 \\
\hline S15 & Human Apolipoprotein A-1 & - & - & -1.47 & 0.934 \\
\hline S16 & Fibroblast growth factor & - & 1.25 & - & 0.982 \\
\hline
\end{tabular}




\begin{tabular}{cccccc}
$\mathbf{S 1 7}$ & $\begin{array}{c}\text { Coiled-coil domain- } \\
\text { containing protein 105 }\end{array}$ & - & - & -1.28 & 0.937 \\
$\mathbf{S 1 8}$ & Transthyretin & 2.31 & - & - & 0.020 \\
\hline
\end{tabular}

3

$\mathrm{S}$ - Protein spot number, - Decreased expression 